\title{
ICT Tools for Implementation the European Qualification Framework in the Agricultural Sector
}

\author{
Miklós Herdon ${ }^{1}$, Róbert Szilágyi ${ }^{2}$, László Várallyai ${ }^{3}$
}

\section{N F O}

Received 21 October 2011

Accepted 14 November 2011

Available on-line 28 November

2011

Responsible Editor: Rajkai, K.

\section{Keywords:}

Agricultural sector, Education, European Qualification

Framework, National

Qualification Framework,

Learning Outcome.

\section{$\underline{\text { A B S T R A C T }}$}

The development of the European Qualifications Framework for Lifelong Learning (EQF) commenced in 2004 in response to requests from Member States, the social partners and other stakeholders for a common reference tool to increase the transparency of qualifications. Although Qualifications within the Agricultural sector in Europe share a common base, each country represents significant geographical differences that result in variable Learning Outcomes. The ImpAQ project (Implement Agriculture Qualification) recognizes the importance of researching different national qualifications in order to contribute to the comparative analysis at national and European level. The ImpAQ aims to compare the Qualifications related to the Agricultural sector, by identifying and analyzing the main issues to be addressed with the purpose of connecting them to the EQF and focusing on the best resolving approaches following the "best fit" criterion. Within the ImpAQ project the consortium developed and applied ICT tools for collecting information from countries of consortium members to build Inventory Database of Agricultural Qualifications and Agricultural Matrix. The matrix cells contain that which qualification entitle for job in the product/process. The Inventory Database and the Agricultural Matrix is used for comparison qualifications. In our article we describe the concept and ICT tools which was used in the project for filling the matrix and uploading information of Hungarian qualifications into the database.

\section{Introduction}

The EQF (European Qualifications Framework) is a common European reference system which will link different countries' national qualifications systems and frameworks together. This will help learners and workers wishing to move between countries or change jobs or move between educational institutions at home. The primary users of the EQF will be bodies in charge of national and/or sectoral qualification systems and frameworks.

The development of the European Qualifications Framework for Lifelong Learning (EQF) commenced in 2004 in response to requests from Member States, the social partners and other stakeholders for a common reference tool to increase the transparency of qualifications. An initial blueprint, proposing an eight level qualifications framework based on learning outcomes, was published by the European Commission and consulted upon in the latter half of 2005. The consultation demonstrated that there was widespread support for the initiative, and a revised text was adopted by the Commission as a proposal in September 2006.

This proposal recommended the establishment of an overarching qualifications framework, which would serve as a translation device to make qualifications more readable and understandable across different countries and systems in Europe (Young, 2010). The core of the EQF consists of 8 qualification levels, which are described through learning outcomes (knowledge, skill and

\footnotetext{
${ }^{1}$ Miklós Herdon

University of Debrecen, Hungary

herdon@agr.unideb.hu

${ }^{2}$ Róbert Szilágyi

University of Debrecen, Hungary

szilagyir@agr.unideb.hu

${ }^{3}$ László Várallyai

University of Debrecen, Hungary

varal@agr.unideb.hu
} 
competence). The principal aims of the EQF are to promote citizens' mobility between countries and to facilitate their lifelong learning. The formal adoption by the European Parliament and Council of the Recommendation establishing EQF was completed on 23 April 2008 (European Parliament Council, 2008).

It is encompasses general and adult education, vocational education and training as well as higher education. The eight levels cover the entire span of qualifications at the end of compulsory education to those awarded at the highest level of academic and professional or vocational education and training. Each level should in principle be attainable by way of a variety of education and career paths.

There are two distinct elements in Implementation of EQF process. Member states are invited:

- to relate their national qualifications levels to EQF, in particular by referencing, in a transparent manner, their qualifications levels to the EQF levels set out in the Recommendation and

- to adopt measures, as appropriate, all new qualification certificates, diplomas and 'Europass' documents issued by the competent authorities contain a clear reference, by way of national qualifications systems, to the appropriate EQF level.

The Recommendation establishing the EQF also advises that Member states designate National Coordination Points (NCPs) to support and, in conjunction with other relevant national authorities, guide the relationship between national qualifications systems and the European Qualifications Framework with a view to promoting the quality and transparency of that relationship. It is recommended that the tasks of NCPs should include referencing levels of qualifications within national qualifications systems to the EQF levels. A transparent methodology is used in the referencing process providing access to information and guidance to stakeholders on how qualifications relate to EQF through national qualifications systems. The participation of all relevant stakeholders (including in accordance with national legislation and practice, higher education (Dill, 2010) and vocational education and training institutions, social partners, sectors and experts) are necessary on the comparison and use of qualifications at the European level.

Europass introduced a portfolio of documents to be used by individuals to describe their qualifications and competences. In the future, all relevant Europass documents, in particular the Europass diploma and the Europass certificate supplement, should contain a clear reference to the appropriate EQF level. The EQF is fully compatible with the qualifications framework for Higher Education developed under the Bologna Process. Specifically, the EQF descriptors at levels 5-8 refer to the higher education descriptors agreed under the Bologna Process. However, the formulation of the EQF level descriptors differs from the Bologna level descriptors developed specifically for higher education needs because, as a lifelong learning framework the EQF also encompasses vocational education and training (VET) and work contexts, including at the highest levels.

QF Embodiment (Exchanging Experiences Gained In Relation To The Establishment Of The National Qualifications Frameworks) project promoted by the Hungarian National Institute of Vocational Education wishes to contribute to one of the main goals of the EQF via the engendering of close cooperation and the exchanging of experiences with the partner countries (Sweden, Spain, Greece, The Czech Republic, Romania and Estonia) and the establishment, convergence and testing of the qualifications frameworks of five selected sectors. Project goals include the provision of an opportunity to discuss the experiences the participating countries gained in terms of the development of their national and sectoral qualifications frameworks as well as the establishment of the qualifications frameworks of the four selected sectoral qualifications contained in the work plan and the convergence thereof to the EQF. Based on documents compiled by experts beforehand, the national and sectoral qualifications frameworks of the partner countries has been presented and tested at a project conference (Karvázi at al., 2009).

The HE-LEO project (Competence Orientation and Learning Outcomes in Higher Education) project wanted to link the European discussions on EQF and on the Bologna Process on an institutional level to the HE-sector. There is a gap between the intended goals and the transformation on an institutional level into daily practice. Therefore, the project aims with an action orientated 
approach to bridge this gap between European policies and an institutional approach of transformation and implementation by focusing on pilot projects in form of case studies in selected subject areas at universities. The main goals of this project are:

- to develop partnerships between national bodies for higher education (ministries) and HEinstitutions for developing mutual trust and exchange of experiences with regard to competence orientation and learning outcomes for the HE-sector related to the EQF;

- to link the discussions on the Bologna process of the HE-sector with the EQF focussing on competence orientation and learning outcomes;

- a comparative synthesis of competence orientation and learning outcomes in the HE-sector on the basis of pilot projects.

Within these goals the main aims of this project are:

- state of the art of competence orientation and learning outcomes in selected subject areas at the partner institutions;

- exchange and transparency about competence orientation and learning outcomes in the selected subject areas in the HE-sector - presentation of good practices as well as areas of conflicts in regard to competence orientation and learning outcomes in the HE-sector using the EQF as common reference point.

The European Qualifications Framework (EQF) provides a common reference framework which assists in comparing the National Qualifications Systems, Frameworks and levels, whether for general and higher education or for vocational education and training (Hegarty, 2010). This online tool allows users to compare their national qualifications frameworks and those of other EU member states and countries participating in Education and Training 2010 programme with the EQF.

EQF E-learning Courses for Eco-Farming (Eco-Farming) was highly successful Leonardo da Vinci pilot project. It developed modules for level 3 (for eco-farmers) and for level 5 (for eco-experts) according to the requirements of the EQF. The project ended in 2008.

\section{Concept, objectives and methods}

The concept is based on a map which provides to the ImpAQ project partners a common reference framework concerning the agriculture sector, in order to enable a coordinated collection of the qualifications in each country (ImpAQ: The Agriculture Matrix, 2010).

\subsection{The function of the map}

The map is the result of 3 cross dimensions (Figure 1.):

- a broader definition of the agriculture sector which includes traditional agriculture, an enlarged vision of agriculture, and multifunctional agriculture;

- a list of the processes occurring according to the analysis of activities related to multifunctional agriculture;

- a selection of the production chains, qualitatively significant and strategic for the development and expansion of agriculture. 


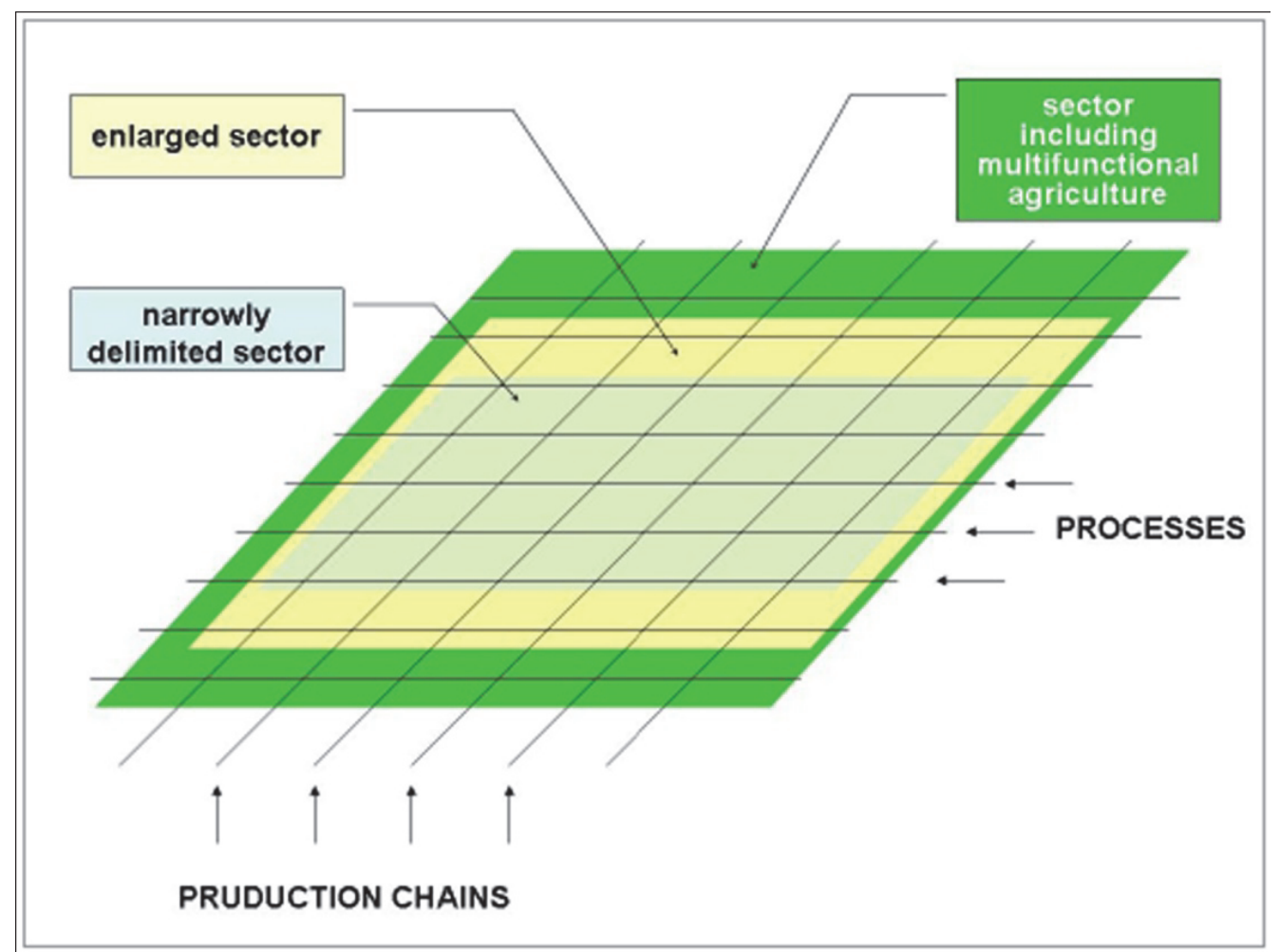

Figure 1. The production chains and processes map (Source: ImpAQ: The Agriculture Matrix, 2010)

The reference perimeter of the agriculture sector is that resulting from the integrated use of the definitions proposed by the European Council (2000), by OECD (2001) and by the U.S. Census Bureau (2002). Here are the definitions slightly revised.

The narrowly delimited sector of Agriculture and Forestry comprises activities primarily engaged in growing crops, breeding and raising animals, and harvesting timber. In some countries, the sector extends to cover the harvesting of fish and other animals from their natural habitats, that is, fishing and hunting. The entities in this sector are often described as farms, ranches, dairies, greenhouses, nurseries, orchards, or hatcheries. The sector distinguishes two basic activities: agricultural/animal production and agricultural support activities.

The enlarged sector includes also entities engaged in agricultural research or in administering programs for regulating and conserving land, mineral, wildlife, and forests. Furthermore, this definition takes into consideration the full agriculture-food (and feed and timber) pathway from land handling to cultivation, harvesting, processing, distribution, and consumption, including quality control and safety.

The multifunctional agriculture sector extends to cover land maintenance, nature and biodiversity custodianship, environmental services linked to ecosystem management, rural preservation, outdoor recreation, ecotourism, traditional craftsmanship, related knowledge development and diffusion/training activities.

\subsection{Objectives of the ImpAQ Project}

ImpAQ project responds to the following European Commission's general objectives:

- support the development, promotion and application of the learning outcomes approach for all qualifications at all levels;

- support the development and implementation of overarching National Qualifications Frameworks (NQFs) based on learning outcomes at all levels;

- support the referencing of national qualifications levels to the EQF in a transparent and credible way supporting mutual trust between countries and sectors. 
ImpAQ specific objectives are:

- Make a comparative analysis of the use of the Learning Outcomes (LO) approach to describe agricultural Qualifications issued in the partner countries.

- Develop guidelines to implement the referencing process by comparing the results of the envisaged comparison adopted in their own countries and those reached by using only the Learning Outcome - LO approach.

- Indicate applicative hypothesis of the different models of the macroscopic, microscopic (in function of the country's having or not a NQF) or combined referencing process comparing the problems and the adopted solutions for the management of the two processes.

- Establish guidelines to increase the coherence of the Qualifications Systems (regional, national and sectoral) by using the best practices analyzed.

- Establish guidelines to coherently achieve the referencing at different levels, according to the present contextual characteristics, by involving the different target groups of the partner countries.

- Produce a synthesis framework which collects precise indications regarding the characteristics of the created NQF and the related construction process, and which specifies operational indications to be submitted to the competent Authorities in the partner countries.

\subsection{Target Group and beneficiary}

ImpAQ is targeted to the agricultural sector's large audience that includes a wide range of entities interested to the EQF:

- Public bodies/other institutions in charge of EQF: National Coordination Points, institutional bodies (ministries of agriculture, education, environment, local bodies), other public research organizations.

- VET/HE agencies and private research organizations: primary/secondary schools, vocational training/research agencies, HE institutions.

- Agricultural sector associations: farmer associations, unions, professional orders, guilds.

The ImpAQ project identifies and analyses National Qualifications within the Agricultural sector in order to compare and link them to the European Qualifications Framework (EQF).

Although Qualifications within the Agricultural sector in Europe share a common base, each country represents significant geographical differences that result in variable Learning Outcomes. ImpAQ recognizes the importance of researching different national qualifications in order to contribute to the comparative analysis at National and European level.

\subsection{Applied methods for collecting the information about Hungarian training programs building the Matrix and Inventory database}

Every partner had to fill in the production chains and processes matrix related to their home countries. This matrix contains the main characteristics of the training programs every EQF defined levels (2-8: from Vocational Education and Trainings to $\mathrm{PhD}$ training programs). We had to collect the necessary information from different sources (Figure 2.) which were the following:

- Institutions

- Ministry of National Resources (Ministry of Education)

- National Institute of Vocational and Adult Education

- Ministry of Rural Development - Rural Development Educational and Advisory Institute

- Universities

- Materials

- Europass - http://nrk.nive.hu/home/?lang[lang]=en

- Professional Qualification Database (Inventory) - http://www.nive.hu

- BSc - Ministry of National Resources - http://www.nefmi.gov.hu/english

- MSc - Ministry of National Resources - http://www.nefmi.gov.hu/english

- $\mathrm{PhD}$ ( http://www.doktori.hu ) - Generally no English description

- University Diploma Supplements - Universities 


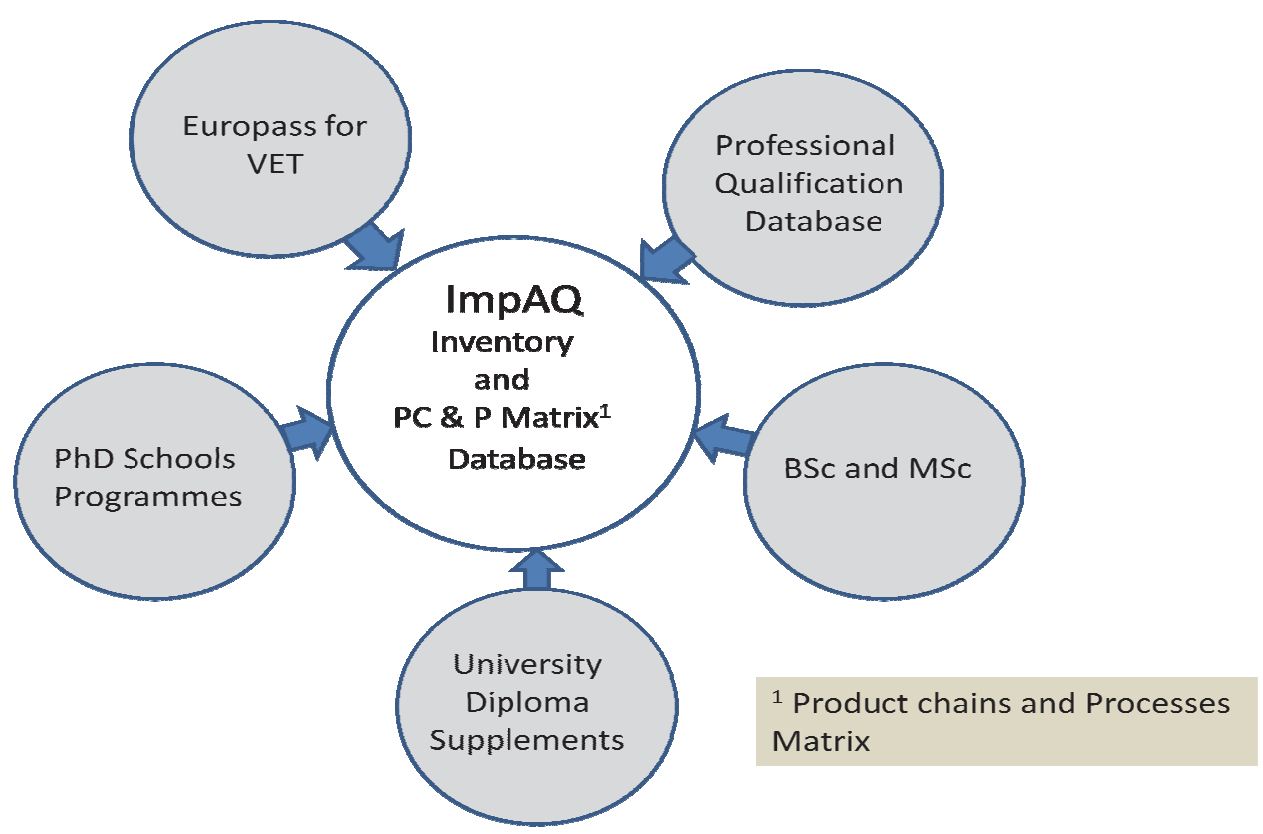

Figure 2. The production chains and processes map (Source: ImpAQ: The Agriculture Matrix, 2010)

The Professional Qualification Database contains description of Vocational Educational Training Programmes. After selecting the agricultural related training programmes from the database the Europass database gave the necessary information about VET Programmes such as the Qualification Type, English Name, EQF, Related Qualification, English Name, Description, Comments, Learning Outcomes were collected from the above sources.

Europass consists of five documents:

- two documents (Europass curriculum vitae (CV) and Europass Language Passport) you can fill in yourself; and

- three other documents (Europass Certificate Supplement, Europass Diploma Supplement and Europass Mobility) filled in and issued by competent organisations.

Europass is supported by a network of National Europass Centres.

Europass has been established by the Decision No 2241/2004/EC of the European Parliament and the Council of 15 December 2004 on a single transparency framework for qualifications and competences.

Information from BSc and MSc education programmes came from Ministry of National Resources and higher education institutes. The University Diploma Supplements are given by Universities to students. There is no national database for this purpose. We had to collect the necessary information about the $\mathrm{PhD}$ training programmes from the Website of Doctorate Schools.

The Qualification Inventory database contains 4 data groups about qualifications from the countries of project members. The data sets are 1. Registry, 2. Structure (of training program), 3. Other information and 4. Qualifications (Figure 3.) 


\section{Qualifications Inventory}

\section{ImpAQ Terminology}

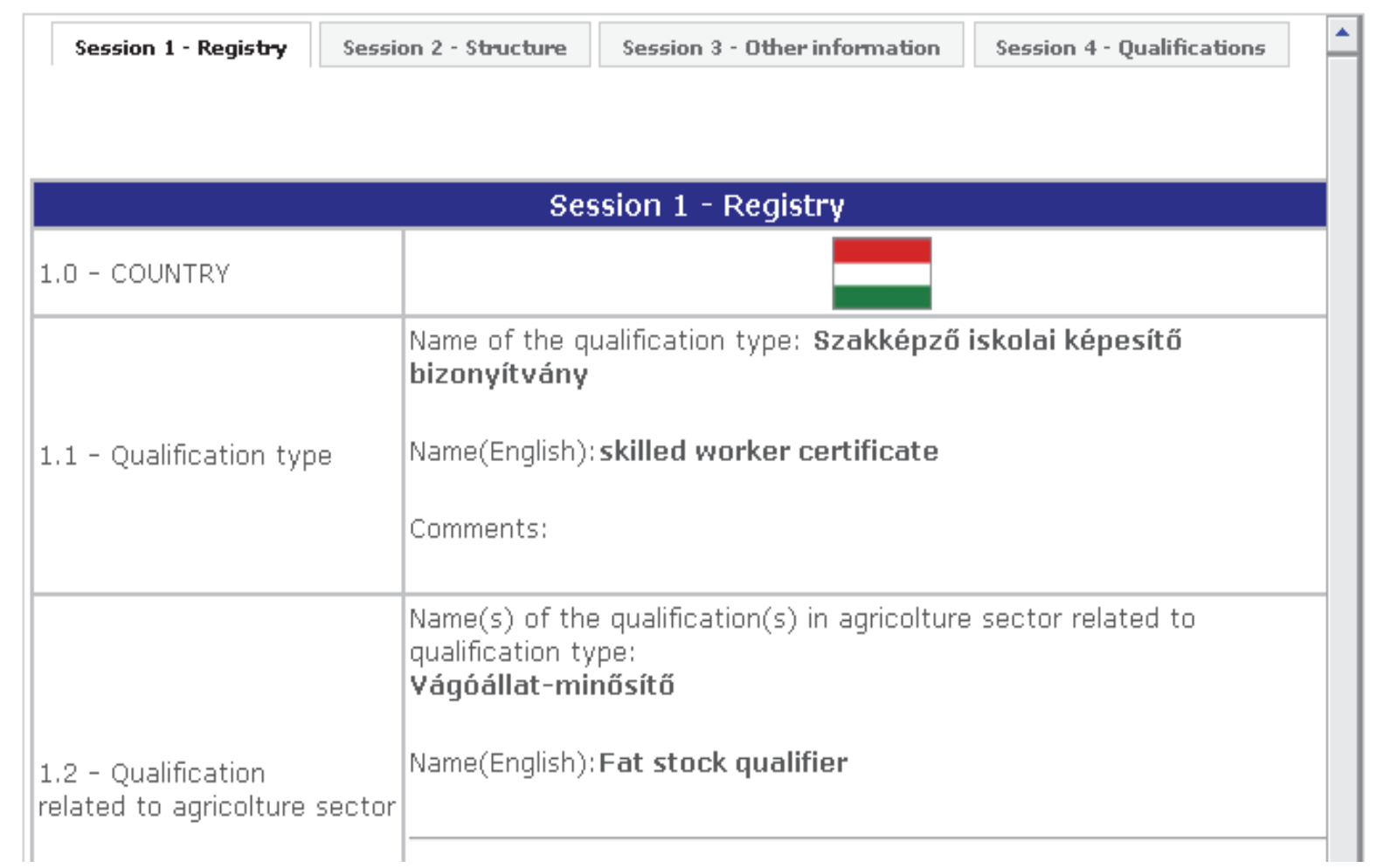

Figure 3. The Qualification Inventory (the first 3 field of Registry dataset)

The qualification dataset contains the Learning Outcomes of the qualification. The Figure 4 show the LO of Fat stock qualifier which information came from Europass database. The Inventory contains information about the following number of qualifications from Hungary: Level 3: 1, Level 3: 35, Level 5: 16, BSc: 13, MSc: 19, PhD: 6. 


\section{ImpAQ Terminology}

\begin{tabular}{|c|c|c|c|}
\hline Session 1 - Registry & Session 2 - Structure & Session 3 - Other information & Session 4 - Qualifications \\
\hline \multicolumn{4}{|c|}{ Session 4 - Qualifications } \\
\hline $\begin{array}{l}4.1 \text { - Learning } \\
\text { Outcomes }\end{array}$ & $\begin{array}{l}\text { Name(s) of the qualific } \\
\text { Name(English): Fat sto } \\
\text { Learning Outcomes: } \\
\text { - A typical holder of } \\
\text { related to the qualifi } \\
\text { prescribed circumst } \\
\text { hygienic, fire and en } \\
\text { authenticity and ade } \\
\text { (instruments, balano } \\
\text { data storage and tra } \\
\text { identification of the } \\
\text { whether the primary } \\
\text { respect to quality co } \\
\text { requirements; - perf } \\
\text { prescriptions; - reco } \\
\text { authentically and to } \\
\text { qualification. } \\
\text { Comments: }\end{array}$ & $\begin{array}{l}\text { k qualifier } \\
\text { e certificate is able to: - } \\
\text { ation of split (half) bodies } \\
\text { oces of the quality control } \\
\text { ironmental protection con } \\
\text { uacy of the equipment to } \\
\text { s, terminals, certification } \\
\text { sfer); - check the preseno } \\
\text { aughter animals and of th } \\
\text { orocessing (which is of pri } \\
\text { trol) at the slaughterhous } \\
\text { rm the classification acco } \\
\text { and document the result } \\
\text { erform the information ta }\end{array}$ & $\begin{array}{l}\text { ofent legal prescriptions } \\
\text { detail; - control the } \\
\text { ite (size, lighting, work-, } \\
\text { tions); - check the } \\
\text { e used in qualification } \\
\text { tamps, equipment for } \\
\text { of signs serving the } \\
\text { split bodies; - check } \\
\text { ary importance with } \\
\text { meets the legal } \\
\text { ing to the legal } \\
\text { of the classification } \\
\text { s related to the }\end{array}$ \\
\hline
\end{tabular}

Figure 4. The Qualification Inventory (the first 3 field of Registry dataset)

\section{Results in portal system development and its application}

\subsection{The requirements of the information portal architecture}

The proposed architecture was based on dialoguing between the web client and the server that can manage the operational database. Web servers are running applications like service middleware, enabling the transfer of three-level architecture of the system, (e.g. client, application server, data server). The application layer is then made operational with tools to enhance the management of distribution and balancing. The web portal provides services for project members (entering the data into the Matrix database, Inventory, etc) and it works as information service for public users. The main page is shown in Figure 5.

\subsection{Application architecture}

The application architecture is proposed according to the three-tier model, realizing the web based technologies (HTML, DHTML, PHP). The objectives of application architecture should be part of the environment to the extreme simplification of presentation (presentation logic) and partly towards the realization of an intermediate component on which to deploy the business logic (middle-tier component), with a third component, the data (logical data) fully accessible by means of standard connectivity. The adoption of multi-layer model for the system is optimal due to the fact that it eliminates any forced options regarding technological features, thus allowing to focus on the development of a more efficient system. 


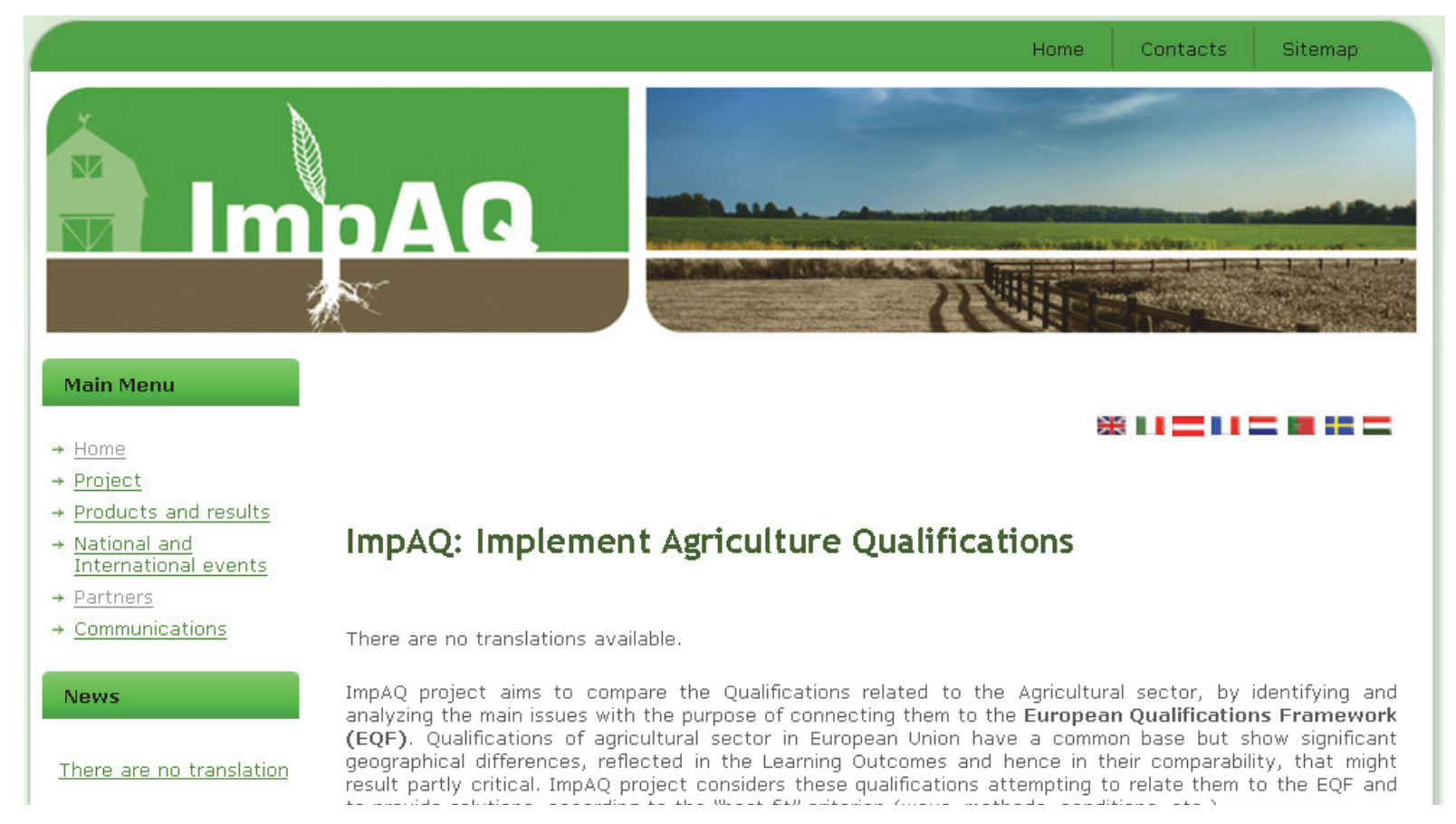

Figure 5. Web portal of the ImpAQ project (Source: ImpAQ Web portal)

The project main server's parameters are the following:

- Application Server: Apache HTTP Server version 2.2.x ;

- PHP version 5.3.x

- RDBMS : MySQL 5.1.x.

The Apache HTTP Server Project is an effort to develop and maintain an open-source HTTP server for modern operating systems including UNIX or Windows. The goal of this project is to provide a secure, efficient and extensible server that provides HTTP services in sync with the current HTTP standards. Apache has been the most popular web server on the Internet since April 1996. The Apache HTTP Server is a project of The Apache Software Foundation.

PHP is a widely-used general-purpose scripting language that is especially suited for Web development and can be embedded into HTML.

MySQL is an open source product, which allows us to reduce cost of production and management systems, but at the same time ensures reliability, scalability and high performance. In fact MySQL has become the de-facto standard for websites with high traffic due to its query-engine, high performance, offering excellent speed both in the operations of data entry and research.

The choice to implement the architecture was the Joomla CMS. Joomla is a content management system platform for publishing content on the World Wide Web and intranets as well as a Modelview-controller (MVC) Web Application Development framework.

The system includes features such as page caching to improve performance, RSS feeds, printable versions of pages, news flashes, blogs, polls, website searching, and language internationalization. It is written in the PHP programming language and uses the MySQL database system to store information.

\subsection{The Agriculture ImpAQ Matrix}

Once coordinators have entered all the data, the platform is accessible by all project partners that could compile the ImpAQ Matrix. Clicking into intersection cells Process/Product (Figure 6 - ImpAQ MATRIX), will be displayed a new page where the user can select one or more qualification type from the drop down list or he can add one or more qualifications through the free text area to the process/product couple, and for each he must assign the EQF level. The number of elements assigned to the couple will be displayed into the cell of the matrix (ImpAQ The Agriculture Matrix, 2010) 


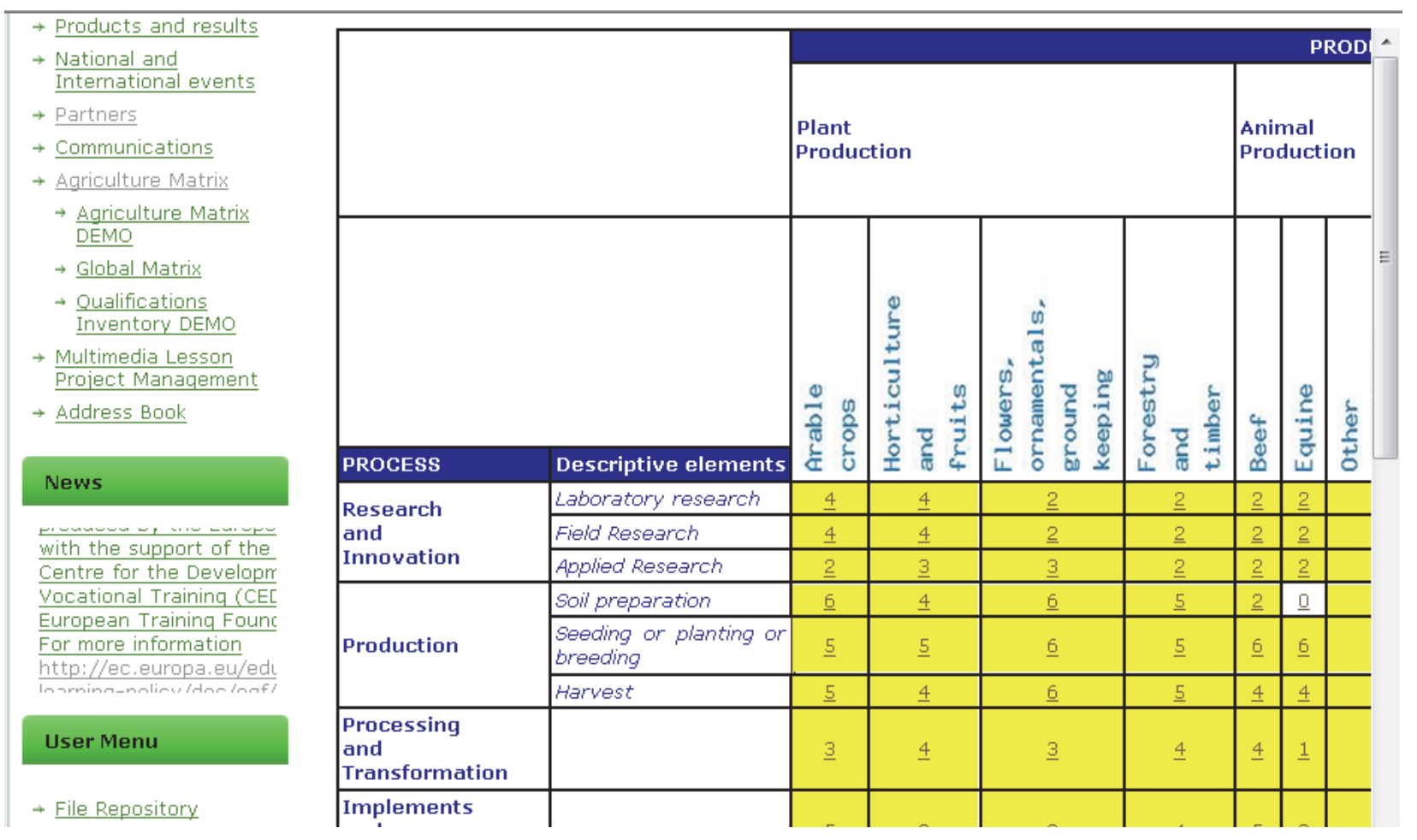

Figure 6. The MATRIX of the ImpAQ (Source: ImpAQ Web portal)

\subsection{The Q-Inventory}

By using this tool, each partner will carry out inventories of qualifications that meet the established criteria and will provide the requested information. The inventory is organized into four sections: Section 1- Registry, Session 2 - Structure, Session 3 - Other information, Session 4 - Qualifications (ImpAQ Analysis tool, 2010)

From the Agricultural Matrix we can access a series of printable reports:

- Overall Preview

- Preview of Description/Comments

- Overall Preview Global

- Related Qualifications for EQF level

- Preview of Description/Comments Global

The first report shows the Qualification type, the English name, the EQF level and the related qualifications filled in for each matrix's intersection of the current country. The second one shows detailed information about each Qualification Type (Qualification Type, English Name, EQF, Related Qualification, English Name, Description, Comments) for the current country. The third one shows the Qualification type, the English name, the EQF level, the related qualifications and its English name filled in for each matrix's intersection grouped for country. The fourth one shows a table containing the number of related qualifications for each country ordered by EQF level and taken only once. The fifth one shows detailed information about each Qualification Type (Qualification Type, English Name, EQF, Related Qualification, English Name, Description, Comments) grouped by country.

\section{Conclusions}

The Qualifications Inventory concerning the Agricultural sector represents the qualifications issued in the partner countries, related to the EQF levels through the analysis of their Learning Outcomes Learning outcomes (both in terms of representation model and content) which help understand what is the quota of common Learning outcomes for the Qualifications comparable at the same level and what is the quota of specific Learning outcomes related to territorial specific features. 
The project's long term impact can concern both project target groups and beneficiaries, the wide range of entities interested to the $\mathrm{EQF}$ and agricultural sector, and the citizens as indirect target group. In detail, the results of the comparison of the EU qualifications of the agricultural sector according the Learning Outcomes approach will produce a pivotal long term impact.

\section{Acknowledgement}

This paper is written by the support of the ImpAQ project. The Implement Agriculture Qualifications Project has been funded with the support of the European Commission. Project number - 167173-LLP-1-2009-1-IT-KA1- Project Coordinator: Università degli Studi "Guglielmo Marconi.

\section{References}

Dill D. 2010. Quality Assurance in Higher Education - Practices and Issues. International Encyclopedia of Education, pp 377-383.

European Parliament Council. 2008. Recommendation of the European Parliament and of the Council of 23 April 2008, Establishment of the European Qualifications Framework for lifelong learning pp 1-7.

Hegarty S. 2010. Education and the European Union, International Encyclopedia of Education, pp 669-675.

ImpAQ: Analysis tool. 2010 Analysis and synthesis Form for Qualifications Inventory Workpackage Number 2: Defining Criteria, Conditions, Tools and Collecting. Relevant Informations for Comparing the Qualifications. Deliverable number 7 Analysis tool Review 1 Implement Agriculture Qualifications Project number - 167173LLP-1-2009-1-IT-KA1- Università degli Studi "Guglielmo Marconi"

ImpAQ: The Agriculture Matrix. 2010. Workpackage Number 2: Defining Criteria, Conditions, Tools and Collecting. Relevant Informations for Comparing the Qualifications. Deliverable number 6 - Analysis tool Review 1 Implement Agriculture Qualifications Project number - 167173-LLP-1-2009-1-IT-KA1- Università degli Studi "Guglielmo Marconi"

Karvázy, E., Liptay, O., Lénárd, S., Várkonyi, A. T., Ónodi, F., Balogh, Z. 2009. Testing of Qualifications in the Light of Relevant National Systems and the EQF in Seven Countries Participating in the Leonardo da Vinci Project QF Embodiment, Nemzeti Szakképzési és Felnőttképzési Intézet, Budapest .

http://qfembodiment.nszi.hu/

Young M. 2010. Qualifications Frameworks and their Role in the Reform of Education and Training. International Encyclopedia of Education, pp 476-481.

\section{Internet sources}

EQF E-learning Courses for Eco-Farming http://www.e-ecofarming.eu/about-the-project.html

EQF leaflet http://www.nqai.ie/documents/eqfleaflet.pdf EQF leaflet.pdf

EQF reference portal http://www.eqf-reference-nqf.net/Default.aspx

EQF-Code project http://ubique.org/eqfcode/

Europass http://europass.cedefop.europa.eu

European Qualifications Framework http://ec.europa.eu/eqf/home_en.htm

Hungarian National Reference Point, http://nrk.nive.hu/

Metal-qf-project http://www.metal-qf-project.eu

METE http://www.mete.mtesz.hu/agrovethu/fin-rep/index.htm

National Institute of Vocational Education www.nive.hu 